\title{
Effects of a single aerobic exercise session on body image
}

\section{ALEXANDRA BÉRES ${ }^{1}$ - EDIT CZEGLÉDI² - BERNADETT BABUSA}

(Received: 24 January 2016, accepted: 30 November 2016)

${ }^{1}$ University of Physical Education, Budapest, Hungary

${ }^{2}$ Semmelweis University, Institute of Behavioral Sciences, Budapest, Hungary

\begin{abstract}
Background and Objectives: Most research on the effects of exercise on body image has concentrated on the benefits of regular exercise. However, some research has indicated that exercise has an immediate impact on body image. The aims of this study were to investigate the immediate effects of aerobic exercise in a fitness class and the at-home environment on body image, and to examine the impact of nutritional status (i.e., normal weight vs. overweight/obesity) and exercise addiction on these changes. Method: 322 Hungarian women participated in the study with two different environmental conditions, fitness class condition $(N=155)$ and at-home video condition $(N=167)$. They completed the Body Appreciation Scale and Exercise Addiction Inventory before and after a one-hour aerobic exercise session. Self-report data on weight, height and exercise frequency were also collected. Results: There were no significant differences between the fitness class and video groups in terms of age, educational level, BMI, body appreciation, exercise frequency and exercise addiction. We found that $7.5 \%(N=24)$ of the participants were at risk for exercise addiction. Aerobic exercise had a significant positive effect on body appreciation $(t(321)=7.564, p<.001)$ independently from environment and nutritional status. Exercise addiction moderated the relationship between exercise and body image, the at risk for exercise addiction group showed the greatest improvement $(F(1)=3.252$, $p=.040)$. Conclusion: The results indicate that even a one-hour aerobic exercise session has a positive effect on body image; this has important practical implications for intervention strategies and weight-loss treatments.
\end{abstract}

Keywords: aerobic exercise, female, body image, exercise addiction, repeated measure

\section{Introduction}

\subsection{Body image and exercise}

Body image is defined as a multidimensional construct - with perceptual, cognitive, affective, and behavioral components - that refers to individuals' perceptions of and attitudes toward their own body, especially its

\footnotetext{
* Correspondence: dr. Bernadett Babusa, Semmelweis University, Institute of Behavioral Sciences, 1085 Budapest, Hungary, Üllői út 26. E-mail: babusa.bernadett@med.semmelweis-univ.hu
} 
appearance (Cash, 2004). Body image dissatisfaction has several negative psychological correlates (see e.g., Sarwer, Thompson, \& Cash, 2005). It could be a risk factor of eating disorders (Stice \& Shaw, 2002), and also mediates the relationship between obesity and mental disorders (Gatineau \& Dent, 2011).

Regular physical activity is considered to have many health-related benefits, as it reduces the risk for cardiovascular diseases, certain cancers and diabetes (U.S. Department of Health and Human Services, 1996) and increases general well-being, creates positive mood, and reduces symptoms of depression and anxiety (Clow \& Edmunds, 2014; Reed \& Ones, 2006). Despite of its beneficial effects the physical activity of the population over 14 years of age in Hungary is insufficient according to the latest data of the European Health Interview Survey (KSH, 2015). Almost half of the population is sitting or standing during work and two-thirds of the population does sport not even ten minutes a day. Only $10 \%$ of the population bicycles on a daily basis. According to the result of this survey more than half of the population is overweight in which development and maintenance physical inactivity plays a key role. Several factors lead to insufficient physical activity such as lack of time, lack of social support, inclement weather, disruptions to routine, lack of access to facilities, and dislike of vigorous exercise (Dunn et al., 1999). This last is particularly unfortunate because exercise, especially cardiovascular exercise with sufficient intensity, duration, and frequency has beneficial effect on body fat percentage and the regional distribution of body fat (McInnis, Franklin, \& Rippe, 2003).

Studies demonstrated a positive relationship between exercise and body image (Koff \& Baumann, 1997; Loland, 2000; Tucker \& Maxwell, 1992; Williams \& Cash, 2001). Since most of these studies investigated the effects of regular exercise on body image, it is argued that body image improvements derive from the changes in body composition and body fat reduction which are consequences of regular exercise, which bring the individual's body closer to the socio-culturally determined ideal. The individual appreciates his or her body much more because of the objective positive physical changes which results body image improvements. On the other hand some evidence emphasize that body image is a multidimensional construct and objective size and perceived physical changes are only one aspect of body image (Cash, 2002). It is also assumed that we feel stronger and thinner following physical activity, as a consequence of exercise that may have a positive effect (McAuley, Marquez, Jerome, Blissmer, \& Katula, 2002; Shaw, Ebbeck, \& Snow, 2000). Consequently, body image may improve as a consequence of perceived body changes, independently from objective physical changes (Depcik \& Williams, 2004; McAuley et al., 2002). 
These results suggest that both perceived and objective physical changes influence body image.

However, body image seems to be a stable construct over time, some evidence suggest that situational factors may have an influence on it (Tiggemann, 2001), revealing that body image has a trait and a state dimension as well. Trait body image is regarded as a stable construct in different contexts and is linked to personality traits. Contrastingly, state body image fluctuates in time and studies revealed that contextual factors - for instance food intake (McKenzie, Williamson, \& Cubic, 1993), food deprivation (Pietrowsky, Straub, \& Hachl, 2003), or current state of mood (Colautti et al., 2011) - have a great influence on it.

Although the immediate impact of exercise is an interesting issue there have been few studies in this research area and the results are sometimes conflicting. McInman and Berger (1993) examined the immediate effects of acute exercise on body dissatisfaction and mood in female participants before and after a sixty-minute aerobic dance session. The control group consisted of university students who completed the questionnaires before and after a university lecture. Compared with the control group attending a lecture, those who took part in the dance session showed significant increases in body satisfaction and mood after the session. However a serious limitation of the study has to be acknowledged since the control group settings do not allow the comparison of the groups. A more recent study also investigated the effects of a single bout of aerobic exercise on body dissatisfaction and mood (Vocks, Hechler, Rohrig, \& Legenbauer, 2009). Results indicated post-exercise body image and mood improvements as participants felt slimmer and were more satisfied with their bodies after the one-hour exercise. Moreover, participants with greater pre-exercise drive for thinness, body dissatisfaction, and weight/shape concerns reported the greater body image improvements. Results of another recent study examined the immediate effects of exercise on body dissatisfaction and mood showed that exercisers experienced less body dissatisfaction and an increase in positive affect after exercise (LePage \& Crowther, 2010). Fuller-Tyszkiewicz, Skouteris, and McCabe (2013) found a bi-directional relationship between exercise and state body satisfaction. Results showed that younger and regular exerciser participants experienced greater postexercise body image satisfaction. Participants with higher BMI and appearance comparison tendencies reported the less body image satisfaction improvements. Finally, Fallon and Hausenblas (2005) investigated the effects of a thirty-minute aerobic exercise session on body dissatisfaction, mood and the impact of exposure to media images of the 'ideal' thin body. 
Although they found significant decreases in body dissatisfaction and depression in the post-test the negative impact of media images was not eliminated.

Although these results are promising there is also evidence that exercise can have negative effects on body satisfaction under some circumstances. Martin Ginis, Jung, and Gauvin (2003) found that women with greater body image concerns experienced increased social anxiety about their physique after physical exercise and women who exercised in front of a mirror felt worse after exercising than women in the unmirrored condition. In another study which investigated the effects of using exercise videos on body dissatisfaction Martin Ginis, Prapavessis, and Haase (2008) found that the greater the discrepancy the exerciser perceived between his or her body and that of the video instructor, the greater the body dissatisfaction after exercising.

\subsection{Exercise addiction}

Recent evidence suggests that some forms of exercise may have negative consequences, this includes exercise addiction, the term used to describe an unhealthy obsession with physical exercise (see e.g., Berczik et al., 2014). Exercise addiction can be defined as excessive exercise behavior accompanied by negative physiological (e.g., withdrawal) or psychological (e.g., anxiety, depression) consequences (Hausenblas \& Symons Downs, 2002) when exercise is not possible. Other authors have defined exercise addiction as an unhealthy reliance on being able to take exercise or a compulsive need to work out, not necessarily to improve performance in competition, but perhaps to deal with daily stress and provide relief from the negative feelings associated with not working out (Baratt, 1994).

Terry, Szabo, and Griffiths (2004) proposed criteria for exercise addiction: (1) salience, exercise becomes the most important activity in the individual's life, dominating thinking, feelings and behaviour; (2) mood modification, the individual experiences mood modification as a consequence of excessive exercise (i.e., arousal-enhancing 'high' effect); (3) tolerance, increasing amounts of exercise are required to achieve the same effects; (4) withdrawal symptoms, unpleasant feelings and/or physical effects (e.g., sleeping disturbances, moodiness, irritability) occur when exercise is discontinued or reduced; (5) conflict, the individual continues to exercise excessively although he or she recognizes that this creates interpersonal conflicts and conflicts with other activities (e.g., job, social life, and hobbies); (6) relapse, rapid reinstatement of the previous pattern of exercise and withdrawal 
symptoms after a period of abstinence. Exercise addiction which develops without any accompanying eating disorder is defined as 'primary exercise addiction' (de Coverley Veale, 1987), whereas in anorexia nervosa excessive exercise is used as weight control strategy and is therefore considered a symptom of the eating disorder and defined as 'secondary exercise addiction' (de Coverley Veale, 1987).

After the first description of exercise addiction, it has been studied in several kinds of sports. Most of the studies examined the exercise addiction in runners (Furst \& Germone, 1993; Hailey \& Bailey, 1982), bodybuilders (Smith \& Hale, 2005), aerobic participants (Kirkby \& Adams, 1996), and triathletes (Blaydon \& Lindner, 2002). Epidemiological studies reported different prevalence rates. Hausenblas and Symons Downs (2002) and Griffiths, Szabo and Terry (2005) found similar 2,5\% and 3\% prevalence rates among habitual exercisers. A study conducted among triathletes reported 52\% rate of exercise addiction (Blaydon \& Lindner, 2002). Another study found $26 \%$ prevalence rate of exercise addiction among male runners and $25 \%$ for female runners (Slay, Hayaki, Napolitano, \& Brownell, 1998). The first Hungarian representative study was conducted in the framework of the National Survey on Addiction Problems in Hungary (NSAPH; Paksi, Rózsa, Kun, Arnold, \& Demetrovics, 2009). Results revealed that $0.3 \%$ of the Hungarian general adult population were at high risk for exercise addiction. Within the framework of NSAPH Mónok et al. (2012) found that 3.2\% of regular exercisers (at least once a week) were at risk for exercise addiction and $52 \%$ were characterized as symptomatic non-dependent exercisers. Another study examined exercise addiction among more than one thousand female fitness exercisers (Béres, Czeglédi, \& Babusa, 2013). The prevalence rate of those who were at risk for exercise addiction was $6.7 \%$, while further $62.4 \%$ of the sample was problematic but non-dependent exercisers.

The relationship between body image satisfaction and exercise addiction is still unclear. Some studies have reported positive associations between body image and the amount of exercise, e.g. Davis and Fox (1993) reported that excessive exercise was associated with greater body satisfaction, whilst others reported negative associations. Hausenblas and Fallon (2002) found that exercise addiction was not a strong predictor of body dissatisfaction, particularly in women.

The main aim of this study was to investigate the immediate effects of a single aerobic exercise (define as a type of physical activity that increases the heart rate and promotes increased use of oxygen in order to improve the overall body condition) on body image in fitness class and at home environment. The secondary objective was to examine the impact of nutritional status (i.e., normal weight vs. overweight) and exercise addiction on these changes. 


\section{Method}

\subsection{Participants}

Participants were 322 Hungarian women engaging in aerobic exercise in different environments, namely aerobic exercise in a fitness class environment (fitness class group, $N=155,48.1 \%$ ) or at-home training with an exercise video (video group, $N=167,51.9 \%$ ). The mean age was 31.2 years $(S D=7.03$ years, range: $18-55$ years). Most of the participants $(77.9 \%)$ were college graduates, $20.2 \%$ were high school graduates and $1.9 \%$ had not completed high school. The mean Body Mass Index (BMI) of participants was $21.6(S D=2.94$, range: 15.50-33.26). According to the World Health Organization criteria $(2000) 9.9 \%(N=32)$ of the participants were underweight $(\mathrm{BMI}<18.5), 77.0 \%(N=248)$ were normal weight $(\mathrm{BMI}=$ $18.5-24.9), 11.2 \%(N=36)$ were overweight $(\mathrm{BMI}=25.0-29.9)$, and $1.9 \%(N=$ 6) were obese $(\mathrm{BMI} \geq 30)$.

\subsection{Measures}

Sociodemographic and anthropometric data. All participants provided data on age, education level, height (in $\mathrm{cm}$ ), and weight (in $\mathrm{kg}$ ); BMI was calculated from these data using the formula weight (in $\mathrm{kg}$ ) / height (in $\mathrm{m}^{2}$ ).

Body Appreciation Scale (BAS; Avalos, Tylka, \& Wood-Barcalow, 2005; Hungarian version: Béres, Czeglédi, \& Babusa, 2013) is a thirteen-item scale developed to measure four aspects of positive body image, i.e., favorable opinions of one's own body, acceptance of the body in spite of imperfections, respect for the body, and protection of the body. All items were rated on a five-point Likert scale $(1=$ never to $5=$ always). Scores range from 13 to 65 , with higher scores indicating greater body appreciation. An investigation of the psychometric properties of the Hungarian version showed that it had good internal consistency (Cronbach's alpha $=.91,95 \%$ CI $[.90, .91])$ and construct validity (Béres et al., 2013). In this study the scale showed good internal reliability (Time 1 Cronbach's alpha $=.87,95 \%$ CI $[.85, .89]$; Time 2 Cronbach's alpha $=.88,95 \%$ CI $[.86, .90])$.

Exercise Addiction Inventory (EAI; Terry et al., 2004; Hungarian version: Demetrovics \& Kurimay, 2008) is a short, six-item scale developed to measure exercise addiction. The inventory is intended to encompass the main characteristics of exercise addiction and includes items on perceived importance of exercise, subjective consequences of exercise, frequency of exercise needed to achieve the desired benefits, presence of withdrawal symptoms, interpersonal conflict attributed to exercising, and possible 
occurrences of relapse. Items are rated on a five-point Likert scale $(1=$ strongly disagree to $5=$ strongly agree). Scores range from 6 to 30, with higher scores indicating behavior associated with exercise addiction. The authors of the EAI have also defined a threshold score for risk for exercise addiction (24), corresponding to the top $15 \%$ of the distribution. They also distinguish between symptomatic non-dependent exercisers (a score of 1323) and individuals who are asymptomatic (a score of 6-12). A recent Hungarian study demonstrated that the EAI has good psychometric properties and also suggested new thresholds: $0-13=$ asymptomatic, 14-23 = symptomatic non-dependent, 24-30 = at risk for exercise addiction (Mónok et al., 2012). In this study we used the modified thresholds (Mónok et al., 2012) to define exercise addiction categories. In previous work with a Hungarian sample the scale demonstrated adequate internal consistency (Cronbach's alpha = .72; Paksi et al., 2009). In our sample Cronbach's alpha was acceptable $(.60,95 \%$ CI $[.53, .66])$.

Exercise frequency. Participants were asked to indicate how frequently they undertook some form of exercise, the response options were (1) less than once a week; (2) once a week; (3) 2-3 times per week; (4) 4-5 times per week; (5) every day and (6) more than once a day. During the analysis response options 1 and 2 were decoded as 'at most once per week' and response options 5 and 6 were decoded as 'every day'.

\subsection{Procedure}

Ethical approval for this study was obtained from Semmelweis University's Regional, Institutional Scientific and Research Ethics Committee. All participants were volunteers; they provided informed consent and were not remunerated for participation.

The participants in the video group condition were recruited via e-mail as they were registered users of a well-known Hungarian fitness website (www.beresalexandra.hu). They were approached via e-mail and were asked to complete an online questionnaire anonymously before (Time 1) and after (Time 2) undertaking a one-hour aerobic exercise session at home following an instruction video. The questionnaire took 10 minutes to complete. The participants in the fitness class condition were recruited at a fitness center in the capital city Budapest and were asked to complete a pencil-and-paper questionnaire anonymously before (Time 1) and after (Time 2) participating in a one-hour aerobic exercise session in the fitness class environment. The questionnaire took approximately 10 minutes to complete.

It was important to control the post-exercise assessment time, as we measured the effects of exercise at only one time point. Changes have been 
reported to be maximal within five minutes of finishing exercise and may last for up to 30 minutes (Ekkekakis, Hall, Van Landuyt, \& Petruzzello, 2000; Focht \& Hausenblas, 2001; Reed \& Ones, 2006; Steptoe \& Bolton, 1988); we therefore chose to measure post-exercise effects within five minutes of completing the aerobic exercise session.

\subsection{Statistical Analysis}

The reliability of the scales was calculated using Cronbach's alpha coefficient and its 95\% confidence interval (95\% CI). Group comparisons were made using the chi-square test for categorical variables and the independent samples $t$-test for continuous variables. Changes in body appreciation were assessed with a paired samples $t$-test and two-way mixed ANOVA. Effect sizes were estimated using Cohen's $d$, with thresholds of .20 for a 'small' effect, .50 for a 'medium' effect and .80 for a 'large' effect (Cohen, 1992).

\section{Results}

\subsection{Characteristics of the Sample}

Participants' exercise frequency varied from at least once a day, 1.5\% $(N=5)$; four to five times per week, $15.9 \%(N=51)$; two to three times per week, $66.6 \%(N=213)$; once a week, $15.0 \%(N=48)$ to less than once a week, $0.9 \%$ $(N=3)$. There were no differences between the fitness class group and video group on any of the study variables (Table 1 and 2).

Table 1. Comparison of Fitness Class Group and Video Group on Continuous Variables.

\begin{tabular}{|l|c|c|c|c|}
\hline \multicolumn{1}{|c|}{ Variable } & $\begin{array}{c}\text { Video group } \\
(\mathbf{N}=\mathbf{1 6 7 )}\end{array}$ & $\begin{array}{c}\text { Fitness class } \\
\text { group } \\
(\mathbf{N = 1 5 5 )}\end{array}$ & $\boldsymbol{t}$ & Cohen's $\boldsymbol{d}$ \\
\cline { 2 - 5 } & $M(S D)$ & $M(S D)$ & & \\
\hline Age in years & $31.3(7.02)$ & $31.0(7.06)$ & 0.430 & 0.05 \\
\hline BMI & $21.8(3.08)$ & $21.5(2.78)$ & 0.782 & 0.09 \\
\hline Body Appreciation Scale - Time 1 & $45.8(8.17)$ & $46.3(7.85)$ & -0.545 & 0.06 \\
\hline Body Appreciation Scale - Time 2 & $47.4(7.83)$ & $47.8(7.59)$ & -0.465 & 0.05 \\
\hline $\begin{array}{l}\text { Exercise Addiction Inventory - } \\
\text { Time 1 }\end{array}$ & $17.6(4.03)$ & $17.5(3.88)$ & 0.093 & 0.01 \\
\hline
\end{tabular}


Table 2. Comparison of Fitness Class Group and Video Group on Categorical Variables.

\begin{tabular}{|c|c|c|c|c|}
\hline \multicolumn{2}{|c|}{ Variable } & \multirow{2}{*}{$\begin{array}{c}\begin{array}{c}\text { Video group } \\
(\boldsymbol{N}=\mathbf{1 6 7})\end{array} \\
39 \\
(23.4 \%)\end{array}$} & \multirow{2}{*}{$\begin{array}{c}\begin{array}{c}\text { Fitness } \\
\text { class group } \\
(\boldsymbol{N}=\mathbf{1 5 5})\end{array} \\
32 \\
(20.6 \%)\end{array}$} & \multirow{2}{*}{$\begin{array}{c}\chi^{2} \\
0.343\end{array}$} \\
\hline Educational level & $\begin{array}{l}\text { Not more than high } \\
\text { school }\end{array}$ & & & \\
\hline & $\begin{array}{l}\text { At least college } \\
\text { graduate }\end{array}$ & $\begin{array}{c}128 \\
(76.6 \%)\end{array}$ & $\begin{array}{c}123 \\
(79.4 \%)\end{array}$ & \\
\hline \multirow[t]{3}{*}{ BMI category } & $\begin{array}{l}\text { Underweight } \\
(\mathrm{BMI}<18.5)\end{array}$ & $\begin{array}{c}16 \\
(9.6 \%)\end{array}$ & $\begin{array}{c}16 \\
(10.3 \%)\end{array}$ & \multirow[t]{3}{*}{0.556} \\
\hline & $\begin{array}{l}\text { Normal weight } \\
(\mathrm{BMI}=18.5-24.9)\end{array}$ & $\begin{array}{c}127 \\
(76.0 \%)\end{array}$ & $\begin{array}{c}121 \\
(78.1 \%)\end{array}$ & \\
\hline & $\begin{array}{l}\text { Overweight or } \\
\text { obese (BMI } \geq 25 \text { ) }\end{array}$ & $\begin{array}{c}24 \\
(14.4 \%)\end{array}$ & $\begin{array}{c}18 \\
(11.6 \%)\end{array}$ & \\
\hline \multirow[t]{4}{*}{ Exercise frequency } & $\begin{array}{l}\text { Not more than once } \\
\text { a week }\end{array}$ & $\begin{array}{c}26 \\
(15.7 \%)\end{array}$ & $\begin{array}{c}25 \\
(16.2 \%)\end{array}$ & \multirow[t]{4}{*}{0.176} \\
\hline & 2-3 times per week & $\begin{array}{c}110 \\
(66.3 \%)\end{array}$ & $\begin{array}{c}103 \\
(66.9 \%)\end{array}$ & \\
\hline & 4-5 times per week & $\begin{array}{c}27 \\
(16.3 \%)\end{array}$ & $\begin{array}{c}24 \\
(15.6 \%)\end{array}$ & \\
\hline & Every day & $\begin{array}{c}3 \\
(1.8 \%)\end{array}$ & $\begin{array}{c}2 \\
(1.3 \%)\end{array}$ & \\
\hline \multirow[t]{3}{*}{$\begin{array}{l}\text { Exercise addiction } \\
\text { category }\end{array}$} & Asymptomatic & $\begin{array}{c}24 \\
(14.4 \%)\end{array}$ & $\begin{array}{c}22 \\
(14.2 \%)\end{array}$ & \multirow[t]{3}{*}{0.060} \\
\hline & $\begin{array}{l}\text { Symptomatic } \\
\text { non-dependent }\end{array}$ & $\begin{array}{c}130 \\
(77.8 \%)\end{array}$ & $\begin{array}{c}122 \\
(78.7 \%)\end{array}$ & \\
\hline & $\begin{array}{l}\text { At risk for exercise } \\
\text { addiction }\end{array}$ & $\begin{array}{c}13 \\
(7.8 \%)\end{array}$ & $\begin{array}{c}11 \\
(7.1 \%)\end{array}$ & \\
\hline
\end{tabular}

Score on the EAI indicated that 7.5\% $(N=24)$ of participants were at risk for exercise addiction; $78.3 \%(N=252)$ of participants displayed some symptoms of exercise addiction, and $14.3 \%(N=46)$ of the sample showed no symptoms of exercise addiction. There were no group differences in exercise addiction categories $\left(\chi^{2}(2)=0.060, p=.970\right)$. A higher proportion of our sample were at risk for exercise addiction than in previously reported international data on physically active populations (Hausenblas \& Symons Downs, 2001: 2.5\%, $\chi^{2}(1)=32.416, p<.001$; Griffiths, Szabo, \& Terry, 2005: 
$\left.3 \%, \chi^{2}(1)=21.946, p<.001\right)$. Prevalence of at-risk for exercise addiction status was higher in our sample than in one recent Hungarian study which used a representative sample of physically active adults $\left(3.2 \%, \chi^{2}(1)=\right.$ $18.806, p<.001$ ), but another study (Béres et al., 2013) reported a $6.7 \%$ rate of at-risk for exercise addiction in a similar population; this did not differ significantly from that observed in our study $\left(\chi^{2}(1)=0.292, p=.589\right)$.

\subsection{Changes in Body Appreciation}

A paired samples $t$-test resulted that body appreciation showed moderate improvement after exercise (Time 1: $M=46.0, S D=8.01$; Time 2: $M=47.6$, $S D=7.70, t(321)=7.564, p<.001$, Cohen's $d=0.60)$. The two-way mixed ANOVA showed no main effect of exercise environment (i.e., fitness class or home) on body appreciation. There was also no significant interaction between time and environment (Model 1).

Nutritional status showed significant main effect on body image. Underweight and normal weight participants (BMI < 25.0, $N=280$ ) were more satisfied with their bodies before and after exercise than overweight and obese counterparts (BMI $\geq 25.0, N=42, F(1)=16.008, p<.001)$. There was no significant interaction between nutritional status and time (Model 2). Results are presented in Table 3, and Figure 1 shows the relationship between nutritional status and body appreciation.

Table 3. Changes in Body Appreciation (two-way mixed ANOVA).

\begin{tabular}{|l|l|c|c|c|}
\hline \multicolumn{1}{|c|}{ Model } & \multicolumn{1}{|c|}{ Variables } & $\boldsymbol{F}$ & $\boldsymbol{p}$ & $\mathbf{\eta}^{\mathbf{2}}$ \\
\hline \multirow{3}{*}{1.} & Time & $56.847^{* * *}$ & $<.001$ & .151 \\
\cline { 2 - 5 } & Environment & 0.271 & .603 & .001 \\
\cline { 2 - 5 } & Environment $\times$ Time & 0.044 & .834 & .000 \\
\hline \multirow{3}{*}{2.} & Time & $26.503^{* * *}$ & $<.001$ & .076 \\
\cline { 2 - 5 } & Nutritional status & $16.008^{* * *}$ & $<.001$ & .048 \\
\cline { 2 - 5 } & Nutritional status $\times$ Time & 0.007 & .934 & .000 \\
\hline \multirow{3}{*}{3.} & Time & $40.587^{* * *}$ & $<.001$ & .113 \\
\cline { 2 - 5 } & Exercise addiction category & $2.420^{+}$ & .091 & .015 \\
\cline { 2 - 5 } & Exercise addiction category $\times$ Time & $3.252^{*}$ & .040 & .020 \\
\hline
\end{tabular}

Note: ${ }^{+} p<.10,{ }^{*} p<.05,{ }^{* * *} p<.001$. 


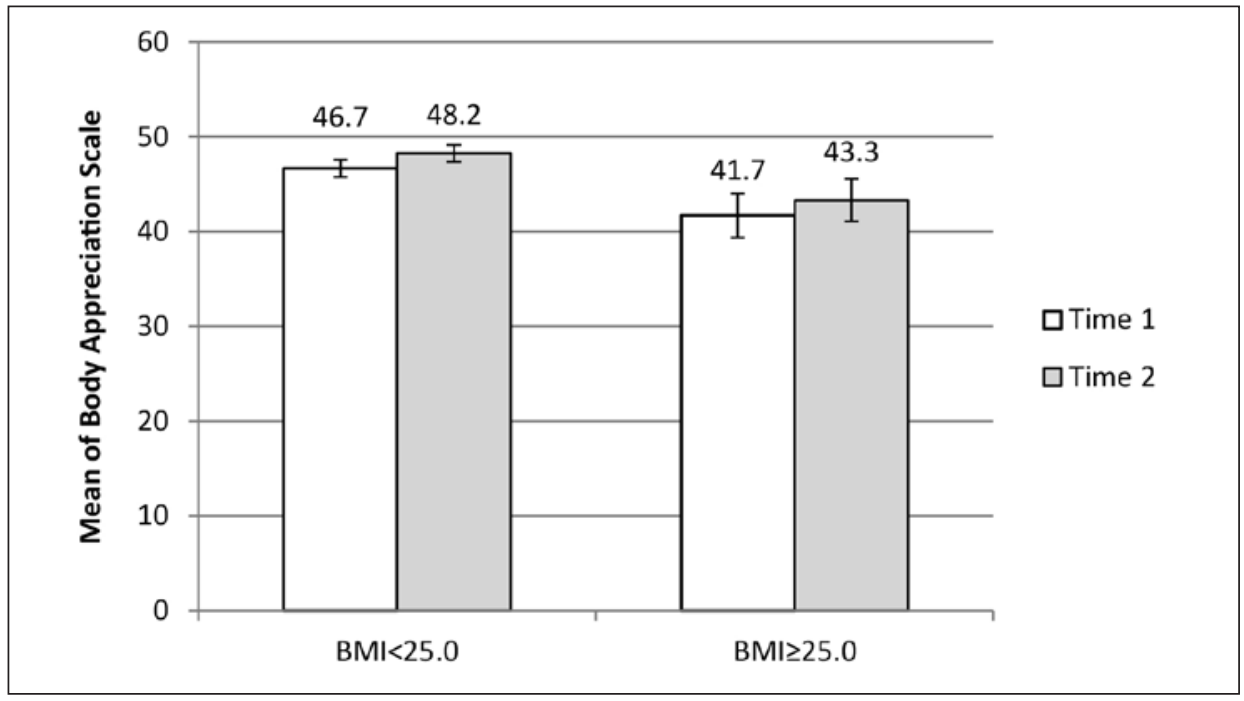

Figure 1. The relationship between nutritional status and body appreciation at Time 1 and Time 2 .

Note: The bars represent means, error bars represent $95 \%$ confidence intervals.

\subsection{Change in Body Appreciation in Different Groups of Exercise Addiction}

The two-way mixed ANOVA indicated that exercise addiction had a marginal main effect on body appreciation $(F(2)=2.420, p=.091)$, asymptomatic exercisers reported the lowest body appreciation, and the atrisk group reported the greatest body appreciation. There was a significant interaction between exercise addiction and time $(F(1)=3.252, p=.040)$, indicating that the at risk for exercise addiction group showed the greatest improvement in body appreciation following exercise (Model 3). Repeated measures ANOVA showed a moderate improvement in body image in asymptomatic (Cohen's $d=0.54$ ) and symptomatic non-dependent groups (Cohen's $d=0.54$ ), and a large improvement in the at risk for addiction group (Cohen's $d=1.86$ ). The results are summarized in Table 3, and Figure 2 shows the relationship between exercise addiction and body appreciation. 


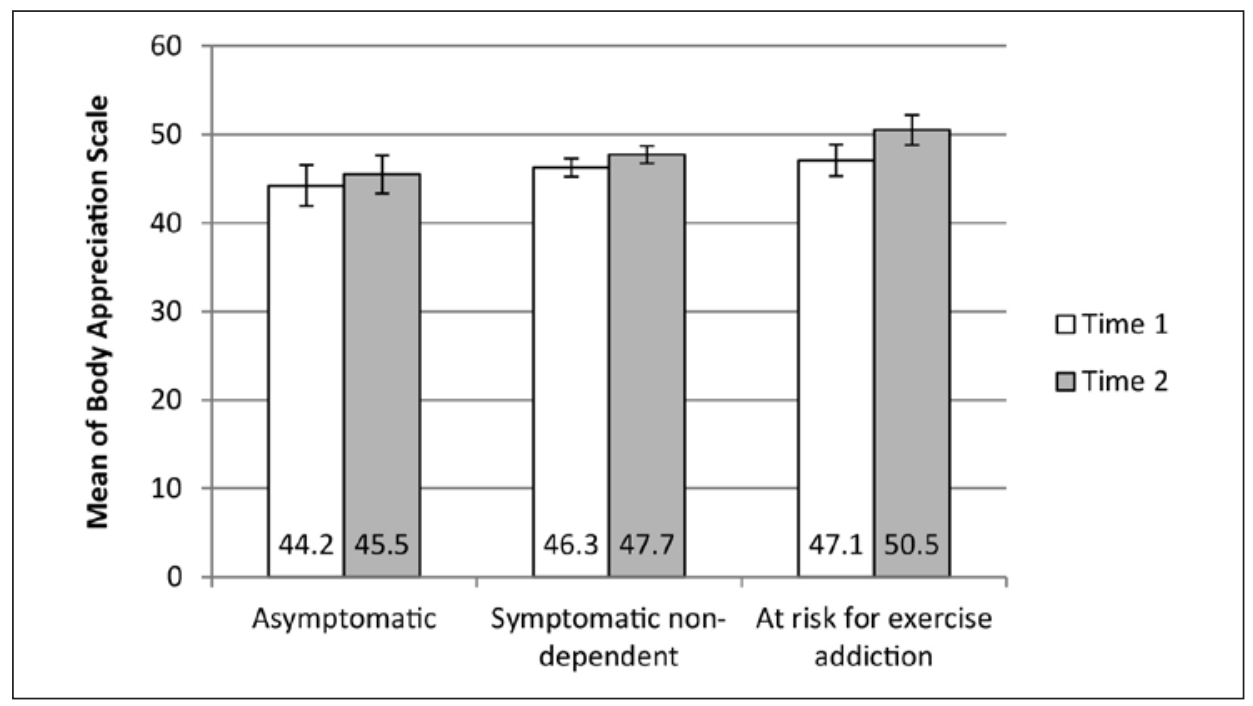

Figure 2. The relationship between exercise addiction and body appreciation in Time 1 and Time 2.

Note: Means and 95\% confidence intervals are shown.

\section{Discussion}

The main aim of this study was to investigate the immediate impact of a one-hour aerobic exercise session on body image (more exactly on body appreciation). The secondary objective was to examine the impact of nutritional status and exercise addiction on these changes. Participants were 322 Hungarian women who engaged in aerobic exercise in a fitness environment (fitness class group, $N=155$ ) or exercised at home using an exercise video (video group, $N=167$ ). There were no group differences in age, educational level, BMI, body appreciation, exercise frequency or exercise addiction.

We found that a one-hour aerobic exercise session had a moderate positive effect on body image, which is consistent with some previously reported results (Fallon \& Hausenblas, 2005; Fuller-Tyszkiewicz et al., 2013; LePage \& Crowther, 2010; McInman \& Berger, 1993; Vocks et al., 2009). Despite the fact that we did not examine changes in mood with regards to this result, mood improvement should also be taken into consideration. Post-exercise measurements of mood have shown increases in positive affect and decreases in negative affects (Choi, Van Horn, Picker, \& Roberts, 1993; Reed \& Ones, 2006), with effects lasting for 30 minutes after exercise although the maximal effect was observed five minutes after exercise (Reed 
\& Ones, 2006). Focht and Hausenblas (2006) found that high levels of social anxiety about physique and the exercise environment were moderators of post-exercise mood changes. Women with high social anxiety about their physique and women exercising in public settings showed a negative change in mood, whereas women exercising in private settings showed positive changes in mood. Based on this result it was advocated that overweight and obese patients should exercise individually, in private settings (e.g., at home) as negative mood may severely impair the chances of achieving long-term weight-loss. However, we were not able to confirm these results since in our study the immediate impact of exercise on body image was similar for the fitness class group and the video group, which implies that the exercise environment does not have any impact on the positive influence of physical activity on body image.

According to our results the improvement in body appreciation proved to be also independent from nutritional status since overweight and obese participants reported similar positive changes compared to underweight and normal weight participants. It has been reported that being stigmatized during gym class leads to feelings of shame in obese children which may severely inhibit their pursuit of formal exercise also in later life (Buckroyd \& Rother, 2007). Given that our results suggest that positive body image changes are independent from the exercise environment, the assessment of exercise related preferences and the reduction of resistances of overweight patients would be beneficial for the successful weight management plan. Highlighting the positive psychological and physical effects of regular exercise for those who are overweight or obese and encouraging individuals who avoid exercise in public - because they are shy or ashamed because of their bodies - to undertake aerobic training at home is also inevitable in successful weight management programs.

Improvements of body image increase self-esteem and reduce psychological symptoms of obesity (Rosen, 2000). It also facilitates the development of more adaptive eating behaviors and physical activities (Palmeira et al., 2009), and mediates the positive effect of self-regulation on eating during behavioral weight-loss interventions (Carraça et al., 2011). There is also evidence that exercise may increase self-esteem through its effects on body image (Haugen, Säfvenbom, \& Ommundsen, 2011; Levy \& Ebbeck, 2005; Sági, Szekeres, \& Köteles, 2012), as concerns about body shape and weight are an important influence on women's self-esteem (Friedman \& Brownell, 1995). Taken together this evidence suggests that our findings have important practical implications for weight-loss treatments. Moreover, since body image dissatisfaction is found to be a strong predictor factor of eating pathology (Stice \& Shaw, 2002), the role of a single bout of aerobic exercise on body image improvement is not 
negligible. Therefore the use of exercise as body image improvement should be considered in prevention and intervention strategies.

In order to explain why even a single session of exercise can produce an improvement in body image it has been suggested that perceived physical changes have more influence on changes in body image than actual physical changes (Martin Ginis \& Bassett, 2011). Perceived changes in physical fitness and physical self-efficacy were found to play a greater role in body image improvements than objective physical changes (Martin Ginis, Bassett, \& Conlin, 2012). Martin Ginis and Bassett-Gunter (2011) emphasized that there is a significant relationship between changes in body image and exercise-induced changes in self-efficacy that represent the sense of personal control, physical mastery, and competence obtained through exercise participation. Our findings are consistent with a previous study showing that in overweight and obese women perceived physical changes (e.g., in body fat and strength) were stronger predictors of improvement in body image than objective physical changes (Martin Ginis, McEwan, Josse, \& Phillips, 2012). These results have a clinical implication; they suggest that weight loss intervention programs should use the improvements in body image induced by perceived physical changes to motivate patients to persist with weight loss and exercise regimes.

Although regular physical activity is considered to be healthy and its positive impact on physical and mental health is well-documented (e.g., Clow \& Edmunds, 2014; U.S. Department of Health and Human Services, 1996), some forms of exercise can be described as 'addictive'. This study is the first investigation of the prevalence of exercise addiction in a Hungarian sample of female aerobic exercisers. We found that $7.5 \%$ of the sample were at risk for exercise addiction, which is higher than the previously reported prevalence of exercise addiction (Griffiths et al., 2005; Hausenblas \& Symons Downs, 2001; Mónok et al., 2012), but similar to our findings in an earlier study of a similar population of women (Béres et al., 2013).

We also examined the potential moderating effect of exercise addiction on changes in body image following exercise using pre- and post-exercise assessments. We found that exercise addiction moderated the relationship between exercise and positive changes in body image, and those who were at risk for exercise addiction showed the greatest improvement in body image after exercise. This finding is consistent with previous reports of a positive association between excessive exercise and body image (Davis \& Fox, 1993; Fuller-Tyszkiewicz et al., 2013). Improvements in body image following exercise may have a rewarding effect which contributes to the maintenance of exercise addiction. It is also speculated that exercise addicted persons use compulsive exercise as an avoidance strategy to escape negative feelings since they experience higher body satisfaction that 
can be also resulted from positive mood changes. Cognitive dissonance may also contribute to the higher level of post-exercise body satisfaction. Based on the diagnostic criteria for exercise addiction (Terry et al., 2004) some forms of exercise addiction need proper treatment. Our finding that aerobic exercise produces a large favorable change in body image (disproportionate to the objective physical changes induced by a single bout of exercise) can be useful for the development of effective interventions. For instance, education about body image and the adaptive body image improvement strategies (designed to discourage extreme and unhealthy exercise routines) would be useful. It would also be interesting to investigate the effects of exercise on body image in men.

Certain limitations to our study must be taken into consideration. One of the most serious methodological limitation is the use of heterogeneous population since the participants were basically recruited from two different places (i.e., fitness classes and via email) which lead to the different environmental conditions (fitness class condition and at-home video condition). Because of this heterogeneity the two groups differ from each other along a number of hidden factors (e.g., motivation, sport history) that may have influenced the results. Thus, the generalization of the study results is strictly limited. The use of convenience sampling and the overrepresentation of highly educated, normal weight participants also severely reduce the generalizability of the results. The absence of a control group of non-exercisers makes it difficult to uncover the body imageenhancing effects of aerobic exercise. The questionnaire we used to measure changes in body image following a one-hour aerobic exercise was not directly developed to measure changes over this time period. However, it could detect the body image changes, future studies may consider the use of more sensible measures for this purpose such as the Body Image States Scale (Cash, Fleming, Alindogan, Steadman, \& Whitehead, 2002). We concentrated on the immediate effects of exercise and did not investigate long-term effects; although our results indicate that exercise has an immediate positive effect on body image, we simply cannot estimate how long this positive effect lasts. No potential confounding factors (e.g., mood, anxiety, body comparison tendencies) were measured and controlled for during the analyses. Another limitation is that there were no objective measures to control the optimal heart rate zone between $65 \%$ and $85 \%$ of maximum heart rate to ensure aerobic exercise intensity (Cooper, 1982). We relied on self-report measures and did not collect objective anthropometric data. The lack of a distinction between primary and secondary exercise addiction is a further limitation. Finally, the small numbers in some of the groups used in the analyses reduced the statistical power of these analyses. 
Because we found that being at risk for exercise addiction was more prevalent in our high risk population of aerobic exerciser women than in a representative sample of the Hungarian general population, it is important to replicate this study using a representative sample; this could provide insight into the factors influencing the relationship between exercise and changes in body image. Future studies should also examine the relationship between exercise and specific psychological changes that are known to affect body image, e.g. improvements in self-efficacy and self-esteem attributed to perceived physical changes have a positive effect on body image and mood (Cash, 2002). Assessment of exercise-related changes in psychological distress would be also useful. Future research should consider the involvement of different populations (e.g., males, clinical populations such as patients with eating disorders) and different exercise modalities. It would be also beneficial to analyze the transition between state and trait body image so as to measure how many exercise session is necessary to have an impact on trait body image.

\section{Conclusion}

In summary, the results of this study demonstrate that even a one-hour aerobic exercise could have a positive effect on body image; individuals who are at risk for exercise addiction are more sensitive to the beneficial effect of exercise on body image. A one-hour exercise session is unlikely to produce enduring changes in body image; however exercise may influence some aspects of body perception and physical competence that could produce short-term improvements in body image. These short-term benefits might serve as a motivation for overweight and obese patients to maintain an exercise regimen over the long term. Moreover, considering the large number of people affected with body image dissatisfaction - which often contributes to the development of severe conditions such as anorexia or bulimia nervosa - the preventive value and benefits of exercise cannot be ignored. Further investigation to explore the underlying mechanisms of these effects using multidimensional measures would be helpful.

\section{References}

Avalos, L., Tylka, T.L., \& Wood-Barcalow, N. (2005). The Body Appreciation Scale: Development and psychometric evaluation. Body Image, 2, 285-297.

Baratt, J.R. (1994). Exercise addiction. In M. B. Mellion (Ed.), Sports medicine secrets (141-144). Philadelphia, PE: Hanley \& Belfus Inc. 
Berczik, K., Griffiths, M.D., Szabó, A., Kurimay, T., Kökönyei, Gy., Urbán, R., \& Demetrovics, Zs. (2014). Exercise addiction - the emergence of a new disorder. Australasian Epidemiologist, 21, 36-40.

Béres, A., Czeglédi, E., \& Babusa, B. (2013). A testedzésfüggőség és a testkép vizsgálata fitneszedzést végző nők körében [Examination of exercise dependence and body image in female fitness exercisers]. Mentálhigiéné és Pszichoszomatika, 14, 91-114.

Blaydon, M.J., \& Lindner, K.J. (2002). Eating disorders and exercise dependence in triathletes. Eating Disorders, 10, 49-60.

Buckroyd, J., \& Rother, S. (2007). Therapeutic groups for obese women. A group leader's handbook. Chichester, UK: John Wiley \& Sons, Ltd.

Carraça, E.V., Silva, M.N., Markland, D., Vieira, P.N., Minderico, C.S., Sardinha, L.B., \& Teixeira, P.J. (2011). Body image change and improved eating self-regulation in a weight management intervention in women. International Journal of Behavioral Nutrition and Physical Activity, 8:75. Doi:10.1186/1479-5868-8-75

Cash, T.F. (2002). Cognitive-behavioral perspectives on body image. In T. F. Cash, \& T. Pruzinsky (Eds.), Body image: A handbook of theory, research, and clinical practice (38-46). New York, NY: Guilford Press

Cash, T.F. (2004). Body image: past, present, and future. Body Image, 1, 1-5.

Cash, T.F., Fleming, E.C., Alindogan, J., Steadman, L., \& Whitehead, A. (2002). Beyond body image as a trait: The development and validation of the Body Image States Scale. Eating Disorders, 10, 103-113.

Choi, P.Y.L., Van Horn, J.D., Picker, D.E., \& Roberts, H.I. (1993). Mood changes in women after an aerobics class: A preliminary study. Health Care for Women International, 14, 167-177.

Clow, A., \& Edmunds, S. (Eds.) (2014). Physical activity and mental health. Leeds, UK: Human Kinetics

Cohen, J. (1992). A power primer. Psychological Bulletin, 112, 155-159.

Colautti, L.A., Fuller-Tyszkiewicz, M., Skouteris, H., McCabe, M., Blackburn, S., \& Wyett, E. (2011). Accounting for fluctuations in body dissatisfaction. Body Image, 8, 315-321.

Cooper, K.H. (1982). The aerobics program for total well-being. New York: Evans

Davis, C., \& Fox, J. (1993). Excessive exercise and weight preoccupation in women. Addictive Behaviors, 18, 201-211.

de Coverley Veale, D.M.W. (1987). Exercise dependence. British Journal of Addiction, 82, 735-740.

Demetrovics, Zs., \& Kurimay, T. (2008). Testedzésfüggóség: a sportolás mint addikció [Exercise dependence: sport as an addiction]. Psychiatria Hungarica, 2, 129-141.

Depcik, E., \& Williams, L. (2004). Weight training and body satisfaction of body-imagedisturbed college women. Journal of Applied Sport Psychology, 16, 287-299.

Dunn, A. L., Marcus, B. H., Kampert, J. B., Garcia, M. E., Kohl, H. W., \& Blair, S. N. (1999). Comparison of lifestyle and structured interventions to increase physical activity and cardiorespiratory fitness. A randomized trial. Journal of the American Medical Association, 281, 327-334.

Ekkekakis, P., Hall, E.E., Van Landuyt, L.M., \& Petruzzello, S.J. (2000). Walking in (affective) circles: Can short walks enhance affect? Journal of Behavioral Medicine, 23, 245-275.

Fallon, E.A., \& Hausenblas, H.A. (2005). Media images of the 'ideal' female body: Can acute exercise moderate their psychological impact? Body Image, 2, 62-73.

Focht, B.C., \& Hausenblas, H.A. (2001). Influence of quiet rest and acute aerobic exercise performed in a naturalistic environment on selected psychological responses. Journal of Sport and Exercise Psychology, 23, 108-121. 
Focht, B.C., \& Hausenblas, H.A. (2006). Exercising in public and private environments: Effects on feeling states in women with social physique anxiety. Journal of Applied Biobehavioral Research, 11, 147-165.

Friedman, M.A., \& Brownell, K.D. (1995). Psychological correlates of obesity: Moving to the next research generation. Psychological Bulletin, 117, 3-20.

Fuller-Tyszkiewicz, M., Skouteris, H., \& McCabe, M. (2013). Re-examination of the benefits of exercise for state body satisfaction: Consideration of individual difference factors. Journal of Sports Sciences, 31, 706-713.

Furst, D.M., \& Germone, K. (1993). Negative addiction in male and female runners and exercisers. Perceptual and Motor Skills, 77, 192-194.

Gatineau, M., \& Dent, M. (2011). Obesity and mental health. Oxford: National Obesity Observatory

Griffiths, M.D., Szabo, A. \& Terry, A. (2005). The exercise addiction inventory: a quick and easy screening tool for health practitioners. British Journal of Sports Medicine, 39:e30. Doi:10.1136/bjsm.2004.017020

Hailey, B.J., \& Bailey, L.A. (1982). Negative addiction in runners: a quantitative approach. Journal of Sport Behavior, 5, 150-154.

Haugen, T., Säfvenbom, R., \& Ommundsen, Y. (2011). Physical activity and global selfworth: The role of physical self-esteem indices and gender. Mental Health and Physical Activity, 4, 49-56.

Hausenblas, H.A., \& Fallon, E.A. (2002). Relationship among body image, exercise behavior, and exercise dependence symptoms. International Journal of Eating Disorders, 32, 179-185.

Hausenblas, H.A., \& Symons Downs, D. (2001). How much is too much? The development and validation of the Exercise Dependence Scale. Psychology and Health, 17, 387-404.

Hausenblas, H.A., \& Symons Downs, D. (2002). Exercise dependence: A systematic review. Psychology of Sport and Exercise, 3, 89-123.

Kirkby, R.J., \& Adams, J. (1996). Exercise dependence: The relationship between two measures. Perceptual and Motor Skills, 82:366. Doi: 10.1177/003151259608200201

Koff, E., \& Bauman, C.L. (1997). Effects of wellness, fitness, and sport skills program on body image and lifestyles behaviors. Perceptual and Motor Skills, 84(2), 555-562.

KSH (2015). Európai lakossági egészségfelmérés, 2014 [European Health Interview Survey, 2014]. Statisztikai Tükör, 2015/29. Retrieved from: https://www.ksh.hu/docs/hun/ xftp/stattukor/elef14.pdf 15.12.2015.

LePage, M.L., \& Crowther, J.H. (2010). The effects of exercise on body satisfaction and affect. Body Image, 7, 124-130.

Levy, S.S., \& Ebbeck, V. (2005). The exercise and self-esteem model in adult women: The inclusion of physical acceptance. Psychology of Sport and Exercise, 6, 571-584.

Loland, N.W. (2000). The aging body: Attitudes toward bodily appearance among physically active and inactive women and men of different ages. Journal of Aging and Physical Activity, 8, 197-213.

Martin Ginis, K.A., \& Bassett, R.L. (2011). Exercise and changes in body image. In: T.F. Cash \& L. Smolak (Eds.), Body image: A handbook of science, practice, and prevention. 2nd ed. (378-386). New York, NY: Guilford Press

Martin Ginis, K.A., Bassett, R.L., \& Conlin, C. (2012). Body image and exercise. In E. Acevedo (Ed.), Oxford handbook of exercise psychology (55-75). London, UK: Oxford University Press

Martin Ginis, K.A., Jung, M.E., \& Gauvin, L. (2003). To see or not to see: Effects of exercising in mirrored environments on sedentary women's feeling states and self-efficacy. Health Psychology, 22, 354-361. 
Martin Ginis, K.A., McEwan, D., Josse A.R., \& Phillips S.M. (2012). Body image change in obese and overweight women enrolled in a weight-loss intervention: The importance of perceived versus actual physical changes. Body Image, 9, 311-317.

Martin Ginis, K.A., Prapavessis, H., \& Haase, A.E. (2008). The effects of physique-salient and physique non-salient exercise videos on women's body image, self-presentational concerns, and exercise motivation. Body Image, 5, 164-172.

McAuley, E., Marquez, D.X., Jerome, J., Blissmer, B., \& Katula, J. (2002). Physical activity and physique anxiety in older adults: Fitness, and efficacy influences. Aging and Mental Health, 6, 222-230.

McInman, A.D., \& Berger, B.G. (1993). Self-concept and mood changes associated with aerobic dance. Australian Journal of Psychology, 45, 134-140.

McInnis, K.J., Franklin, B.A., \& Rippe, J.M. (2003). Counseling for physical activity in overweight and obese patients. American Family Physician, 67, 1249-1256.

McKenzie, S.J., Williamson, D.A., \& Cubic, B.A. (1993). Stable and reactive body image disturbances in bulimia nervosa. Behavior Therapy, 24, 195-207.

Mónok, K., Berczik, K., Urbán, R., Szabo, A., Griffiths, M.D., Farkas, J., Magi, A., Eisinger, A., Kurimay, T., Kökönyei, Gy., Kun, B., Paksi, B., \& Demetrovics, Zs. (2012). Psychometric properties and concurrent validity of two exercise addiction measures: a population wide study. Psychology of Sport and Exercise, 13, 739-746.

Paksi, B., Rózsa, S., Kun, B., Arnold, P., \& Demetrovics, Zs. (2009). A magyar népesség addiktológiai problémái: Az országos lakossági adatfelvétel az addiktológiai problémákról (OLLAAP) reprezentatív felmérés módszertana és a minta leíró jellemzői. [Addictive behaviors in Hungary: The methodology and sample description of the national survey on addiction problems in Hungary (NSAPH)]. Mentálhigiéné és Pszichoszomatika, 10, 273-300.

Palmeira, A.L., Markland, D.A., Silva, M.N., Branco, T.L., Martins, S.C., Minderico, C.S., Vieira, P.N., Barata, J.T., Serpa, S.O., Sardinha, L.B., \& Teixeira, P.J. (2009). Reciprocal effects among changes in weight, body image, and other psychological factors during behavioral obesity treatment: A mediation analysis. International Journal of Behavioral Nutrition and Physical Activity, 6:9. Doi:10.1186/1479-5868-6-9

Pietrowsky, R., Straub, K., \& Hachl, P. (2003). Body dissatisfaction in female restrained eaters depends on food deprivation. Appetite, 40, 285-290.

Reed, J., \& Ones, D.S. (2006). The effect of acute aerobic exercise on positive activated affect: A meta-analysis. Psychology of Sport and Exercise, 7, 477-514.

Sági, A., Szekeres, Zs., \& Köteles, F. (2012). Az aerobik pszichológiai jólléttel, önértékeléssel, valamint testi tudatossággal való kapcsolatának empirikus vizsgálata női mintán [Relationships among aerobic exercise, psychological well-being, self-esteem, and body awareness in women - An empirical study]. Mentálhigiénéés Pszichoszomatika, 13, 273-295.

Sarwer, D.B., Thompson, J.K., \& Cash, T.F. (2005). Body image and obesity in adulthood. Psychiatric Clinics of North America, 28, 69-87.

Shaw, J.M., Ebbeck, V., \& Snow, C.M. (2000). Body composition and physical self-concept in older women. Journal of Women and Aging, 12, 59-75.

Slay, H.A., Hayaki, J., Napolitano, M.A., \& Brownell, K.D. (1998). Motivations for running and eating attitudes in obligatory versus nonobligatory runners. International Journal of Eating Disorders, 23, 267-275. 
Smith, D.K., \& Hale, B.D. (2005). Exercise dependence in bodybuilders: Antecedents and reliability of measurement. Journal of Sport Medicine and Physical Fitness, 45, 401-408.

Steptoe, A., \& Bolton, J. (1988). The short-term influence of high and low intensity physical exercise on mood. Psychology and Health, 2, 91-106.

Stice E, \& Shaw H.E. (2002). Role of body dissatisfaction in the onset and maintenance of eating pathology: A synthesis of research findings. Journal of Psychosomatic Research, 53, 985-993.

Terry, A., Szabo, A., \& Griffiths, M.D. (2004). The Exercise Addiction Inventory: a new brief screening tool. Addiction Research and Theory, 12, 489-499.

Tiggemann, M. (2001). Media influences on body image development. In T.F. Cash, \& T. Pruzinsky (Eds.), Body image: A handbook of theory, research, and clinical practice (91-98). New York, London: Guilford Press

Tucker, L.A., \& Maxwell, K. (1992). Effects of weight training on the emotional well-being and body image of females: Predictors of greatest benefit. American Journal of Health Promotion, 6, 338-344.

U.S. Department of Health and Human Services, Centers for Disease Control and Prevention, National Center for Chronic Disease Prevention and Health Promotion. (1996). Physical activity and health: A report of the Surgeon General. Retrieved from: http:/ / www.cdc.gov/ nccdphp/sgr/pdf/sgrfull.pdf 10.01.2016.

Vocks, S., Hechler, T., Rohrig, S., \& Legenbauer, T. (2009). Effects of a physical exercise session on state body image: The influence of pre-experimental body dissatisfaction and concerns about weight and shape. Psychology and Health, 24, 713-728.

Williams, P. A., \& Cash, T. F. (2001). The effects of a circuit weight training program on the body images of college students. International Journal of Eating Disorders, 30, 75-82.

World Health Organization (2000). Obesity: Preventing and managing the global epidemic. Report of a WHO Consultation (WHO technical report series No. 894). Retrieved from: http://whqlibdoc.who.int/trs/WHO_TRS_894.pdf?ua=1 11.05.2015.

\section{Conflict of Interests Statement}

The authors have no conflict of interest to declare.

\section{Division of labor}

The authors took part in the following processes in connection with the preparation of the present article. First author: study design and organization, data collection, the preparation of all sections of the present article. Second author: data analysis, results description, final review of the article. Third author: study design and supervision, article concept, final review of the article. 


\section{Egyalkalmas aerobik edzés hatása a testképre}

\section{BÉRES ALEXANDRA - CZEGLÉDI EDIT - BABUSA BERNADETT}

Elméleti háttér és célkitüzés: Bár a legtöbb kutatás a rendszeres testedzés testképre gyakorolt pozitív hatására fókuszál, néhány vizsgálat eredménye a testedzés testképre tett azonnali hatására hívja fel a figyelmet. Jelen tanulmány célja az aerobik edzés testképre gyakorolt azonnali hatásának vizsgálata fitnesztermi és otthoni edzési körülmények között, továbbá a tápláltsági állapot (normális testsúly vs. túlsúly/elhízás) és a testedzésfüggőség potenciális moderátor szerepének vizsgálata az edzés és a testkép alakulása közötti kapcsolatban. Módszer: A vizsgálatba aerobikedzést folytató nőket vontunk be $(\mathrm{n}=322)$. A résztvevők egyik része edzőteremben folytatta a testgyakorlást $(n=155)$, másik része otthon végzett aerobik testedzést, video vagy DVD segítségével $(n=167)$. Mérőeszközök: önbeszámolóval nyert testtömeg és testmagasság, a testedzés gyakoriságára vonatkozó kérdés, Testértékelési Skála, Testedzés Addikció Kérdóív. Az adatfelvétel az egyórás testgyakorlást megelózően és azt követően történt. Eredmények: Nem találtunk szignifikáns különbséget az edzőteremben és az otthonukban aerobik edzést folytató nők között az életkor, az iskolai végzettség, a BMI, a testértékelés, a testedzés gyakorisága és a testedzésfüggőség tekintetében. A válaszadók 7,5\%-a $(n=24)$ esetében jelenik meg a testedzésfüggőség kockázata. Az egyórás testedzés szignifikáns, kedvezó hatást gyakorolt a testképre $(t(321)=7,564$; $p<0,001$ ), amely hatás a testgyakorlás helyszínétől (edzőterem vs. otthon) és a tápláltsági állapottól függetlennek bizonyult. A testedzésfüggőség azonban moderálta a testgyakorlás és a testkép változásának kapcsolatát: a testedzést követően a testedzésfüggőség szempontjából veszélyeztetett csoportban mutatkozott meg a legnagyobb mértékú, pozitív irányú változás a testkép tekintetében $(F(1)=3,252 ; p=0,040)$. Következtetés: Eredményeink arra utalnak, hogy akár egy egyórás testgyakorlásnak is pozitív hatása lehet a testképre, amelynek jelentős gyakorlati implikációi vannak a testsúlycsökkentő kezelések szempontjából.

Kulcsszavak: aerobik edzés, nők, testkép, testedzésfüggőség, ismételt mérés 